\title{
Alternative Scheme for Handling Reversely the Waste of Mobile Phone in Bandung, Indonesia
}

\author{
Bagus Arthaya ${ }^{1, *}$, Eliza Nathania ${ }^{2}$
}

\begin{abstract}
Waste and other second-hand goods management in Indonesia are still not properly managed, while used products still have their economic value. E-waste is one of many second-hand goods that are not handled properly. E-waste is defined as the rubbish of electronic products. Mobile phone is one of the electronic products that are almost used by most of Indonesian people, ranging from people having low income to those having a huge income. The influence of lifestyle makes mobile phone lifespan is very short. High level of consumption and short life time make mobile phones are not used accordingly and quickly become waste. When this waste is not managed properly then it will accumulate and damage our nature, because almost all mobile phone components are nonorganic materials. Used mobile phones still have economic value and some of their components can be recycled or reused. Therefore this study focuses on promoting reverse handling management of used mobile phones from the Indonesian consumers. The main strategy is aligned with Reverse Logistics concept where value recovery and proper disposal become the main consideration. In this design, a strategy will be discussed throughout the stakeholders who will be involved in the return process so the process can run effectively and efficiently. Consideration of recycling or reusing used product can reduce the retrieval of raw materials from the nature. The problem solution will certainly have an impact on our natural resources balance. When this strategy works successfully then it will certainly contribute in preserving of nature.
\end{abstract}

Keywords- economic value, e-waste, recycle and reuse, reverse logistic, used product.

\section{INTRODUCTION}

$\mathbf{T}$ HE use of electric and electronic equipment (EEE) is tremendously increasing in Indonesia in the last decade. One cannot definitely live without EEE now days, such as mobile phones, TV-sets, stereo-sets, music players, computers, fridges and so on. Direct consequence of it is increasing number of used devices in relatively very short period and finally become the most growing hazardous and toxic waste stream when they are not managed properly.

Every year the world produces 40 million tons of electronic waste: from TVs to refrigerators to cell phones and computers and this figure will only increase. For instance, by 2020, China is expected to throw away seven times more cell phones than now, and India 18 times more. These hightechnology goods not only are bulky, they often contain toxic materials such as lead and mercury. If the e-waste is not taken care of properly, it can cause pollution and health hazards [1].

It is reported that sales of electronic goods continue to soar until the next decade is expected to occur in developing countries in the next 10 years. Increased sales, of course affects the accumulation of electronic waste that is harmful to the environment and human health. United Nations
Environmental Program (UNEP) warned that developing countries need anticipate the danger of electronic waste. Developing countries will become the landfills area by the developed countries. "Today the world is facing a wave of devastating invasion of electronic waste, especially in developing countries," said Achim Steiner, UNEP Executive Director, as reported by Cellular-News [2].

Waste and other second-hand products management in Indonesia is still not wisely managed and taken care, while used products still in fact have their economic value. One of waste and other second-hand goods that are not handled properly is the electronic waste (E-waste). E-waste is defined as the rubbish of electronic products or widely known as Waste of Electrical and Electronic Equipment (WEEE).

This type of E-waste is a non-homogeneous complex mixture in term of materials and components. Because of their hazardous content, and if not properly managed, it can cause major environmental and health problems.

Mobile phones are the most intensively used EEE especially by the Indonesian youngsters and as well by Indonesian adult, ranging from the low income society to the have. One person can have typically until two hand phone units, even sometimes more. Research result shows that Indonesia is forecasted to be one of the biggest smartphone users in the world [3] as shown in Fig. 1.

\begin{tabular}{|c|c|c|c|c|c|c|}
\hline \multicolumn{7}{|c|}{$\begin{array}{l}\text { Smartphone Users and Penetratio } \\
\text { by Country, 2014-2019 } \\
\text { millions and \% of mobile phone users }\end{array}$} \\
\hline & 2014 & 2015 & 2016 & 2017 & 2018 & 2019 \\
\hline \multicolumn{7}{|c|}{ Smartphone users (millions) } \\
\hline China* & 482.7 & 525.8 & 563.3 & 599.3 & 640.5 & 687.7 \\
\hline India & 123.3 & 167.9 & 204.1 & 243.8 & 279.2 & 317.1 \\
\hline Indonesia & 44.7 & 55.4 & 65.2 & 74.9 & 83.5 & 92.0 \\
\hline Japan & 46.2 & 51.8 & 55.8 & 58.9 & 60.9 & 62.6 \\
\hline South Korea & 32.2 & 33.6 & 34.6 & 35.6 & 36.5 & 37.0 \\
\hline Philippines & 21.8 & 26.2 & 29.9 & 33.3 & 36.5 & 39.2 \\
\hline Vietnam & 16.6 & 20.7 & 24.6 & 28.6 & 32.0 & 35.2 \\
\hline Thailand & 15.4 & 17.9 & 20.0 & 21.9 & 23.4 & 24.8 \\
\hline Taiwan** & 15.1 & 16.4 & 17.2 & 17.8 & 18.3 & 18.6 \\
\hline Australia & 13.5 & 14.6 & 15.4 & 16.0 & 16.5 & 16.8 \\
\hline Malaysia & 8.9 & 10.1 & 11.0 & 11.8 & 12.7 & 13.7 \\
\hline Hong Kong & 4.4 & 4.8 & 5.0 & 5.2 & 5.3 & 5.4 \\
\hline Singapore & 3.8 & 4.0 & 4.2 & 4.3 & 4.4 & 4.6 \\
\hline New Zealand "* & 2.3 & 2.7 & 2.9 & 3.1 & 3.2 & 3.3 \\
\hline Other & 57.1 & 72.1 & 86.6 & 100.4 & 113.3 & 125.4 \\
\hline Asia-Pacific & 888.0 & $1,023.9$ & $1,139.8$ & $1,254.7$ & $1,366.3$ & $1,483.4$ \\
\hline
\end{tabular}

Fig. 1. Asia-pacific smartphone users till 2019 [1].

Other important aspect that also contributes significantly to the production of E-waste is changing lifestyle of Indonesian society in the last decade.
${ }^{1}$ Department of Mechatronics Engineering, Parahyangan Catholic University, Gd. 10, Lt 2, Jl. Ciumbuleuit No. 94, Bandung, Indonesia.

${ }^{2}$ Alumni of Industrial Engineering Magister Program, Parahyangan Catholic University, Jl. Merdeka No. 30, Bandung, Indonesia.

*Correspondence to Bagus Arthaya, email: bagusart@unpar.ac.id. Tel.:+62-22-2032700; fax.:+62-22-2032700. 
The influence of this changing lifestyle also makes mobile phone lifespan very short because people buy a new unit before the former phone is completely broken. This shortage of utilization accelerates the replacement of outdated equipment. High number of consumption and short life time make mobile phones are not used accordingly and eventually become E-waste. If this waste is not taken care properly then the waste will accumulate and will burden the environment. It can degrade the quality of our nature, because almost all mobile phone components are un-organic materials.

But new way of seeing the problem is arising lately as a consciousness about the economic value in this waste. Used product may not be seen as a waste, but it must be seen as new resource, so it should be managed accordingly. Again, Achim Steiner, the agency's secretary-general, says much of the e-waste should be recycled. Beyond the environmental reasons, there is also an economic incentive, he says: for example, three percent of the gold and silver mined worldwide is used in personal computers and mobile phones [3]. He points out that investing for recycling and reusing these used product, then you have turned a problem into an opportunity, where you can create jobs, reduce the use amount of metals and you can reuse them.

Outdated mobile phones in fact still have their economic value and some of their components can be reused or recycled entirely [4], although some of the materials are highly toxic. Therefore this study will focus on promoting a reverse handling management strategy of used mobile phones from the hands of consumers. The main strategy is aligned with Reverse Logistics concept where value recovery and proper disposal become the main considerations.

In this study, a typical strategy will be discussed among the stakeholders who will be involved in the return process for running the process effectively and efficiently. It is very important to understand and realize that most components of a mobile phone still have their economic values. Materials and components of mobile phones can be reused or recycled and it certainly can reduce the retrieval of raw materials from the nature. Just imagine what would happen when our universe is constantly exploited for this purpose. Furthermore, these problems will certainly have an impact on our natural resources balance. When this strategy is successfully implemented then we will eventually take part in the preservation of nature resources and reduce the environmental burden.

\section{WASTE OF ELECTRONIC AND ELECTRICAL EQUIPMENT}

European Commission declares in its website (http://ec.europa.eu/environment/waste/weee/index_en.htm) that "WEEE is a complex mixture of materials and components that because of their hazardous content, and if not properly managed, can cause major environmental and health problems. Moreover, the production of modern electronics requires the use of scarce and expensive resources (e.g. around $10 \%$ of total gold worldwide is used for their production). To improve the environmental management of WEEE and to contribute to a circular economy and enhance resource efficiency the improvement of collection, treatment and recycling of electronics at the end of their life is essential".

Two directives i.e. WEEE Directive and RoHS Directive have been put in place to address the massive problems to deal with. These directives designate the safe and responsible collection, recycling and recovery procedures for all types of electronic waste as well as the usage restriction of certain hazardous substances in electrical and electronic equipment.

Despite the directive's attempts to control and to handle Ewaste properly and strictly, Indonesia still lacks of a specific regulation for WEEE (although there are some regulations concerning of handling poisonous and harmful materials). Indonesian people must understand the risk and extreme danger of throwing away E-waste improperly to the environment and should know the basic principle of handling and managing this kind of waste as well.

\section{A. The Role of Reverse Logistics (RL)}

In contrary to Direct/Forward Logistic, Reverse Logistic per definition can be defined as a process of planning, implementing, and controlling the efficient, cost effective flow of used materials, used goods and related information from the point of consumption to the point of origin for the purpose of recapturing value or proper disposal, and is more precisely mentioned in RL Magazine [5, 6].

This definition can clearly explain that RL is much more than just reusing the containers or recycling the packaging material as well as the used products. The main objective is to recover economic values of used product through an efficient and effective way and at once minimize the amount of waste in doing so and properly dispose the waste if any. Blumberg [6] has suggested a closed loop supply chain scheme for typical high-tech products such as mobile phone or other electronics devices that will certainly employ this scheme completely as portrayed in Fig. 2

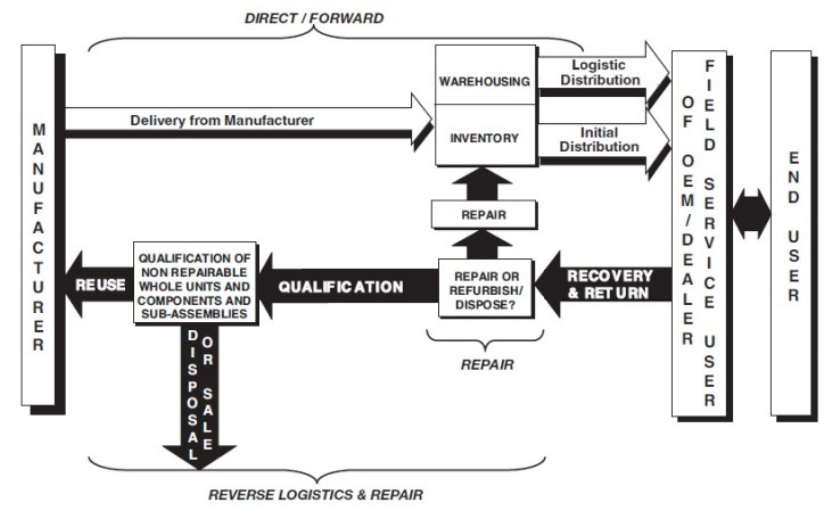

Fig. 2. Typical high-tech closed loop supply chain [6].

Used goods should be collected from the end user by field service user of OEM and sent back to manufacturer through some screening processes, such as repair/refurbish or dispose and some qualifying assessments. For this purpose some strategy should be implemented and qualified personals must be employed.

Used products are often defined as solid waste and in some categories it is classified as hazardous waste. Mobile phones may typically produce solid and hazardous waste, and this urges to be managed properly. Two approaches generally employ i.e. waste management and waste reduction. Choosing the second as the strategy then any waste produced by the consumers are considered to be potential resources that can be reused, recycled, or remanufactured (3R). This strategy certainly needs the RL management to ensure the $3 R$ activities happen. Instead of managing the waste, reducing is the more prioritized. 
To optimize the process of bringing back the used materials and used products as well as the packaging from point of consumption to the point of origin, some activities (as listed in Table 1) must be carefully managed and executed. In this study, only one product type is discussed and a basic scheme to bring back the used products to the point of origin while maintaining the economic values they still contain.

Coordination between all stakeholders to manage these activities play important role to the success. In this paper, only the product side will be discussed that contains 10 main activities. Meanwhile, the treatment of packaging side has not been developed, although it may contribute significantly to the success of value recovery and proper disposal program.

Table 1. Common RL activities

\begin{tabular}{cll}
\hline \hline No. & Materials & \multicolumn{1}{c}{ RL Activities } \\
\hline 1 & Product & Return to Supplier \\
& & Resell \\
& Sell via Outlet \\
& & Salvage \\
& Recondition \\
& & Refurbish \\
& & Remanufacture \\
& & Reclaim Materials \\
& & Recycle \\
& & Landfill \\
& & Reuse \\
& & Refurbish \\
& Packaging & Reclaim Materials \\
& & Recycle \\
& Salvage \\
\hline \hline
\end{tabular}

The first 4 activities mainly deal with returning process of used product, and the second 4 deal with process of recovering value from the used/outdated product, while the last action is dealing with disposal of the waste.

\section{B. The Role of Inverse Manufacturing (IM)}

Kimura [7] mentioned that reducing the environmental burden such as resource consumption and disposal, while keeping the proper service level products offer to customers can be effectively done by considering the product design and manufacturing preparation concurrently, and also to design the total product life cycle as a whole from product planning, throughout product design and manufacturing, to product usage, maintenance and reuse/recycling/disposal. This approach is then called "inverse manufacturing".

While Xerox company [8] points out that the inverse manufacturing aims at designing and manufacturing products with less environmental loads by reusing parts, and realizing "zero emission" aiming at full utilization of products by selecting out parts which cannot be reused and using them as resources. This concept is integrated in a closed loop system and now is called Integrated Recycling System. Even, they claimed to dispose E-waste only $3 \%$ of their copy machine components.

In general inverse manufacturing concerns with redesigning manufacturing processes and products to use less material and energy as well as redesigning manufacturing processes to produce less waste and pollution. In addition is to develop products that are easy to repair, reuse, remanufacture, compost, or recycle and at once eliminate or reduce unnecessary packaging.

\section{THE FACT OF USED MOBILE PHONES IN INDONESIA}

Some research works have been carried out by various agencies like e-Marketer, Statista etc. [1, 2], and the results show a significant increasing number of mobile phone users in Asia Pacific as well as in Indonesia although those two agents showed a different forecasting amount. The statistic done by Statista [2] shows in Fig.3 the total number of mobile phone users in Indonesia from 2013 to 2019. For 2017 the number of mobile phone users is expected to rise to around 173 million. Immediate consequence is that the number of outdated EEE may pose environmental as well as health risks from exposure to heavy metals when they are improperly disposed.

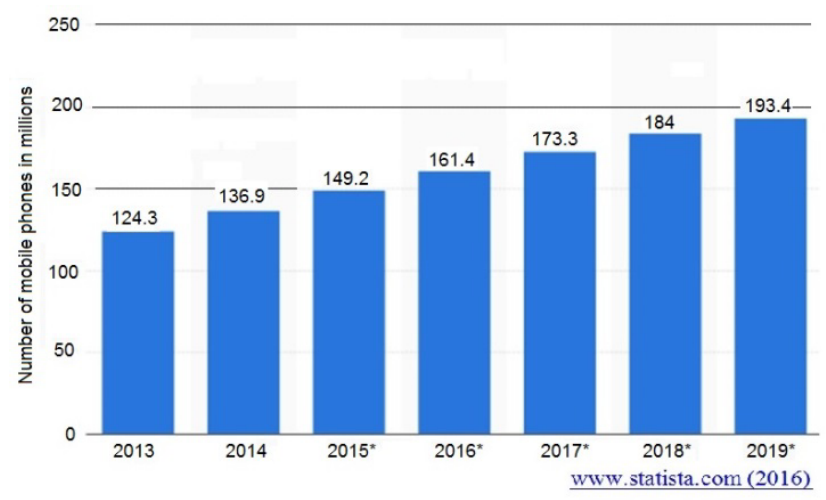

Fig. 3. Number of mobile user in Indonesia between 2013-2019.

Indonesian people in general still do not pay attention to the potential of environment and health risks pose by the hazardous elements or materials of mobile phones. Outdated units are just thrown away and end up as product at the second market. No serious actions are taken by the manufacturers as they think the outdated/used products are not their responsibility anymore.

Wahyono [9] delivered findings in his research that some regions (in Indonesian: kabupaten) such as: Bogor, Tangerang, Tangerang Selatan, Tegal and East Jakarta are unconsciously exposed from heavy metal. The problems arose mostly related to improper E-waste recycling process that introduces high content of heavy metal inside the blood of the local citizen. People show very low responsibility to preserve their local invorenment by improperly disposing hazardous matertials to the earth. 


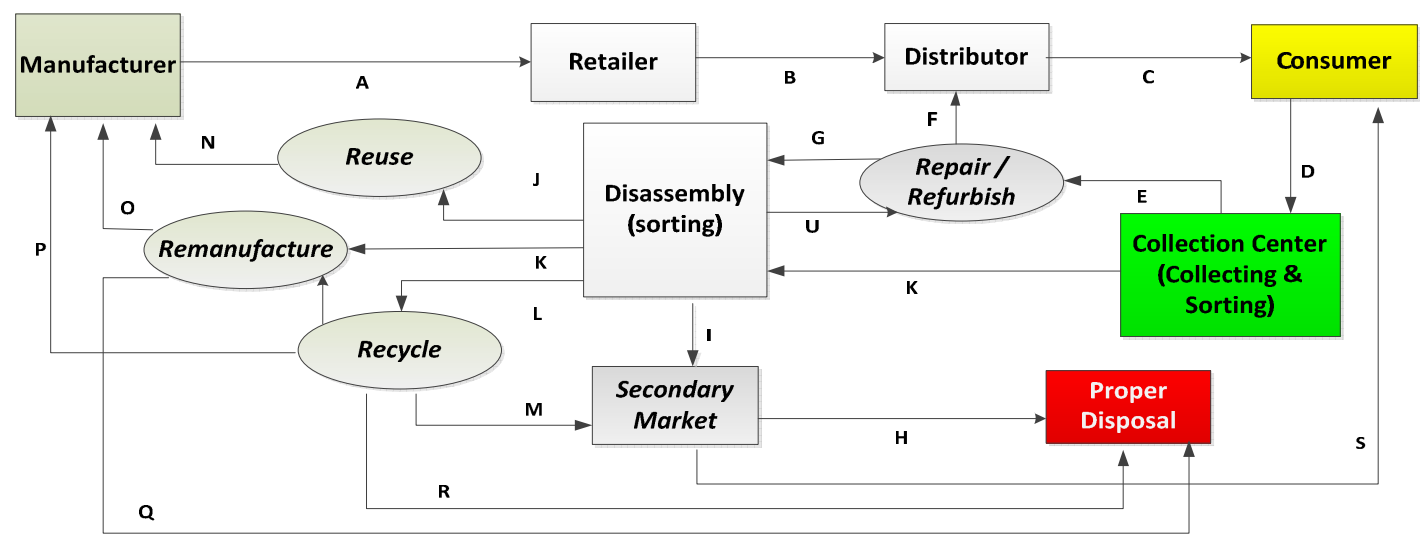

Fig. 4. Reshaped closed loop scheme for handling used mobile phones

Table 2. Meaning of symbols in the reshaped closed loop scheme Fig.4

\begin{tabular}{ccl}
\hline \hline No. & Symbol & \multicolumn{1}{c}{ Explanations } \\
\hline 1 & A & brand new mobile phone \\
2 & B & brand new mobile phone \\
3 & C & brand new mobile phone \\
4 & D & used (second-hand) mobile phone \\
5 & E & used (second-hand) mobile phone \\
6 & F & mobile phone that has been repaired \\
7 & G & the remaining components repair \\
8 & H & components that must be discarded \\
9 & I & components that will be sold on the \\
& & secondary market \\
10 & J & components to be reused \\
11 & K & components to be remanufactured \\
12 & L & components to be recycled \\
13 & M & raw materials are sold at secondary market \\
14 & N & components to be reused \\
15 & O & components that have been remanufactured \\
16 & P & recycled raw materials \\
17 & Q & waste from remanufacture process \\
18 & R & waste from recycle process \\
19 & S & mobile phone with lower quality \\
20 & T & second-hand mobile phone \\
21 & U & components to be reused \\
\hline \hline
\end{tabular}

A similar phenomenon happens in Selangor, where Malaysians are nowday able to own more than one type of electrical equipments or multiple units of the same type of the type such as mobile phones as the increase in purchasing power and the generally affordable prices. The way they disposed the E-waste is quiet the same, such as donate, sell to second hand market, give to scrap collector and so on [10].

Yet, action must be done urgently as danger from destructed environment may deteriorate human life soon. In Indonesia, government must become the stimulator and the patron, academic society should take part in promoting the importance, the manufacturer should not hide from the reality and society should be educated to deal with E-waste. All of these parties must work together to start managing E-waste from the simplest way or strategy.

\section{HANDling of Used MobILE PHONes}

\section{A. Closed Loop Scheme for Returning Phone Waste}

A new closed loop scheme to tackle mobile phone waste is introduced as depicted in Fig. 4 and in Table 2, where it is mainly based on RL scheme in Fig. 2. Main concern of this scheme is the "collection center" that takes care of collecting and sorting actions. This part is fortunately aligned with the program of Bandung mayor, that he will make the Bandung Champion, where collection center of used product is one major consideration. Sustainable solid waste management is the main concerned of recycle center. Government plans to develop ecovillage to provide recycle center that recycling plastics, batteries, paper metal biomatter, glass, textile, electronics, and composite. [11]. The other deep attention is minimizing disposal by persuasion to the society not to waste and softly enforcing law related to environmental issues. Consumer ought to take part as well by following instructions related to disposal of their used mobile phones.

The chain from manufacturer, retailer, distributor, and consumer is the part of forward logistics (arrow A, B, and C in Fig.4). Both distributor, retailer, and even manufacturer still have not understood and realized that there are so many accumulations of outdated mobile phone in the market that needs their responsibility from RL point of view. They focus mainly on innovatng and generating new technology to increase mobile phone sales. As consciousness about preserving nature and environment in the world is increasing, then reverse flow of used material/product from point of distribution is urgently to be realized and implemented. As the concequence, those three parties mentioned above must be forced to play their role and to take part in this woeking scheme.

It is a logical way to recover value of the used product and properly dispose after all value is recovered. Reverse logistics consist of collection center, secondary market, repair/ refurbish process, disassembly, reuse, remanufacturing, and proper disposal functions. Manufacturer of mobile phones in this scheme also includes all sub-contractors that produce all components for manufacturing the mobile phone. They distribute their products to the distributors through their retailer. In fact there are so many mobile phones manufacturers selling their product in Indonesia, and the number of foreign manufacturer is even bigger, such as from Taiwan, US, Canada, China, India and so on. All of them should be encouraged to contribute to this program. 
Retailer is the connecting agent between manufacturer and distributor. Foreign manufacturers must have business cooperation with local retailer to distribute their products across Indonesia which in fact this retailer is very helpful to this extent. PT Metrodata Electronics Tbk. for instance is the authorized retailer for OPPO product in Indonesia [12]. OPPO manufacturer just need to send their products to Metrodata, and this retailer will distribute the product to all regions acrosss Indonesia. Concerning the new scheme in Fig. 4 , this retailer must have responsibility to activate and integrate local player/distributor as their team to collect used/outdated product from consumers.

Similarly to retailer, distributor plays their role in distributing the mobile phone products, but they also function to bridge the retailer and consumers. Consumer cannot by mobile phone from retailer even manufacturer, yet they got it from distributor. There are so many mobile phone distributors in Indonesia, one of them is PT. Trikomsel Oke Tbk. [13]. They have famous factory outlets called Oke Shop spreading in many cities across Indonesia. The shop doesn't sell only one brand, but they also sell different brands and various types of mobile phones. Variety of selling method by distributors makes a very complicated flow of business. They may sell their product to outlets or sell it online. Variety of manufacturers, retailers, and distributors makes the forward logistics of mobile phone very complex.

In general, mobile phone consumers are all people or parties that utilize mobile phone products. Now days, almost everyone in Indonesia possess one mobile phone, even some types of mobile phone are sold very cheap because this kind of products are available in more affordable prices. The poor then can buy this kind of product to ease their communication activities

Wijayanti findings show that changing life style contributes to increasing number of mobile phone consumption and decreasing life time of the product [14]. They also mentioned that changing life style influences positively and significantly to consumer behavior in buying mobile phone. Meanwhile Budijati et.al [15] show that there were three post consumption behaviors identified i.e.: sell to second-hand market, storage/donated to others, and direct discarding, meanwhile there was no consumer who were willing to return to a take back program.

Collection center plays very important role in this reverse logistic scheme because the process won't run smoothly when consumers won't take part actively. Collecting points must be placed in the shortest reaching distance to the consumers. Moreover, publication about reverse logistics and the advantages to people and environment should be announced intensively so that consumer will have deep consciousness to bring used/outdated mobile phone to the collection center. Based on survey done in [16], mostly people love to choose a market centers as a place for collection center for used/outdated electronic devices. In this center, sorting process is a mandatory activity to check the quality of used mobile phone to determine whether the unit needs to be repaired or to further processed (disassembled). Repairable mobile phone will be fixed or refurbished and break down mobile phone will go to disassembly process.
Repair/refurbish center performs repairing/refurbishing process to bring product to the operatable state if not to original state. Repair is only performed for repairable units, and the distinction between repairable and break down product must be determined.

Disassembly process is important to take out all components. Each of the components will be sorted and classified into groups only by the authorized experts from different of manufacturers. This action should be very strict in order to maintain the high quality that still contained by the parts. These groups then go to the reuse, remanufacture, or recycle processes. A good quality component will be directly reused for a new product. Some of them may need remanufacturing operations and the rest will continue to recycling process. This means almost all component will continue to follow the forward logistic of mobile phone products in the next cycle.

Secondary markets are the place where customers can buy the used/repaired mobile phone. The condition of this mobile phone is fairly good, but some functions may not work properly or at least it has been used by others if it still works perfectly.

Components that cannot be repaired, reused, recycled, and remanufactured as well as the waste of remanufacturing process then must be sent in a proper way to safe disposal area. Every waste needs correct and detailed treatment before sent to the landfill to minimize the impact to the environment.

\section{B. Proposal for Management Strategy for Reversely Handling Phone Waste}

Process of transporting used/outdated product from point of distribution to point of origin (manufacturing) is a complex job and it needs a very intense coordination between involved stakeholders. Manufacturer plays very important role in realizing this RL concept. User must have a good and deep understanding that used product they deliver cannot be thrown away anymore but must be considered as new resources to be used again. Government on the other hand has to monitor, control and execute regulation about handling the used products especially E-waste.

Furthermore, RL also includes recycling programs, hazardous material handling programs, obsolete equipment disposition, and economic value recovery. Wahyono [9,I] points out some valuable materials extracted from used product, i.e. plastic, glass, iron and steel, precious metal (silver, gold, platinum, copper), and rare earth elements such as Scandium, Yttrium, Serium, Neodimium, etc.

$\mathrm{He}$ also warned that improper processing the used product may introduce very dangerous materials. Melting used battery may emit heavy smoke containing lead $(\mathrm{Pb})$, while chemical extraction will produce heavy metals like mercury $(\mathrm{Hg})$, lead $(\mathrm{Pb})$, Chromium $(\mathrm{Cr})$, and cadmium $(\mathrm{Cd})$, as well as dioxin to the earth and water. Process of cable burning introduces smoke containing dioxin or polychlorinated dibenzo-pdioxin/furan (PCDD/F). This data should have awaken us and give a better understanding what is tragically happening around us.

The proposal of handling used mobile phones must ensure the maximum capability for extraction of valuable materials and minimum emission of hazardous materials to the 
environment. Practical movements should be introduced by the government that can be used to influence 1) the quantity of returns, 2) the maintained quality (configuration and condition) of used goods, and 3) the moment of supply to the collection center.

Strategy introduced can increase the possibilities for recovery and reuse as people still don't see the (economic) potentials of used/outdated goods. This strategy proposes some actions, such as:

a) Take back action, encouraging responsibility of the producers/manufacturers.

b) The government offers special tax incentives for manufacturers that take part to this program.

c) Trade-in actions, when people buy a new product.

d) Public partnership, dealer/shop participation in providing collection corner in their spots.

e) Public movement, daily action by society to separate used phone and bring to adjacent collection center.

f) Soft law enforcement to persuade people to start taking part to government regulation and environmental programs.

g) Campaign about the management strategy to handle Ewaste (just done by Komuitas Earth Hour in Bandung in Februari 2017 to increase society consciuousness about the high risk of E-waste [17].

Bandung government's program for promoting "Recycle Center", encourages all stakeholder in Bandung to take part to this program in minimizing E-waste to the environment as depicted in Fig. 5. This program is a big frame to make Bandung Champion Movement (called Bandung Juara) which aligned with Collection Center action shown in Fig. 2. When all parties in this figure contribute proportionally, then some significant leap occurs in reducing burden to the nature.

Bandung mayor is the conductor of this program, followed by the municipal government and local universities as well as electronic goods manufacturers supporting it. Even visitor of Bandung needs to be educated as they are also in some extent become the contributor to environmental problem in Bandung.

Incentive program may be carried out as proposed by De Brito [18], for instance rubbish collectors do their work collecting and sorting all mobile phones and other E-waste in this center and are paid base on number (amount) of works they've performed. This is much better then they work as their own way and the result may decrease product quality.

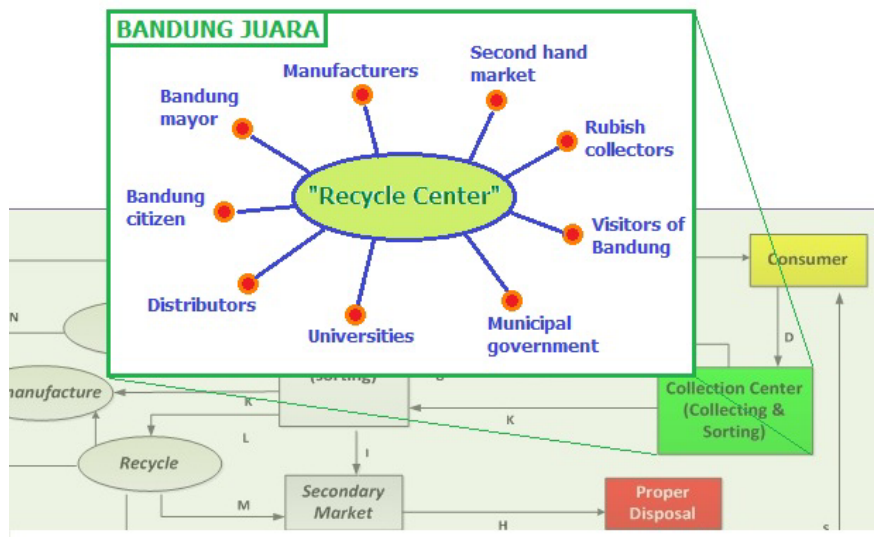

Fig. 5. Recycle center to implement collection center in Bandung.
Extended Producers Responsibility (EPR) should be enforced which in some countries has become mandatory for producers. Association of Indonesia Electronic Entrepreneurs (Gabungan Pengusaha Elektronik Indonesia) has not accepted the idea as they claimed to increase production cost, tight competition in electronic business and high variety of production scale [9].

There are at least 14 government regulations to deal with harmful and hazardous materials issued by Indonesian government. One of them is PP RI No. 18/1999 Jo. PP No. 85/1999: about handling of hazardous and poisonous materials. It obliges anyone or manufacturers to manage harmful and hazardous materials they produced. So it is very strict that every citizen must obey rules from the government. This regulation will be certainly able to support the success of reverse logistic program of used mobile phones. Handling hazardous material.

\section{CONCLUSION}

E-waste is a new topic worldwide that urgently ought to be solved not only by government but by participation of all stakeholders. A lot of consumers have understood the importance to carefully handle used product that may produce hazardous element to the environment. But the way out to smoothly collect the products is still enough not provided.

The turn of manufacturers has now come to take part in preserving the nature and environment by actively collecting used products that originally been produced in their site. Their responsibility is now a mandatory and company image is at stake. Government regulations have directed to manage the waste related to their production processes as well as the product they produced when it comes to the end of life.

Aligned with Bandung government program to make Bandung Champion, this closed loop scheme will contribute significantly to encourage all stakeholders to take part. In accordance to their competence, each party in Bandung Juara scheme can start their role and action to this program.

\section{REFERENCES}

[1] S. Honorine, "E-Waste Creates Economic, Environmental Problem for Developing Nations" Available: http://www.voanews.com/a/ indonesian-e-waste-85035327/112911.html (Access on Thu, 23 February 2017)

[2] http://andreanvyscalatyn96.blogspot.co.id/2012/11/limbah-elektroniksemakin-menumpuk_28.html_(Access on Sat, 2 April 2016).

[3] http://www.emarketer.com/Article/Asia-Pacific-Boasts-More-Than-1Billion-Smartphone-Users/1012984 (Access on Sat, 2 April 2016).

[4] W. He, et.al., "WEEE Recovery Strategies and the WEEE Treatment Status in China". [Online]. Journal of Hazardous Material. 2006, pp. 502-512. Available: http://www.paper.edu.cn

[5] Reverse Logistic Magazine http://www.rlmagazine.com/ edition01p12.php (Access on Sat, 2 April 2016).

[6] D. F. Blumberg, "Introduction to Management of Reverse Logistics and Closed Loop Supply Chain Processes", CRC Press, Florida, 2005.

[7] F. Kimura, "Life Cycle Design for Inverse Manufacturing", Proceedings of EcoDesign '99: First International Symposium On Environmentally Conscious Design and Inverse Manufacturing, IEEE Xplore Digital Library, 1999.

[8] Fuji Xerox Integrated Recycling System, Available: https://www.fujixerox.com/eng/company/ecology/cycle/ (Access on 2 March 2015).

[9] S. Wahyono, "Electronic Waste Management Policies in the Scope of Global and Local.” J. Tek. Ling. Vol. 14, No. 1, Januari 2013, pp. 17 24. (E-ISSN 2548-2101) 
[10] J. A. Kalana, "Electrical And Electronic Waste Management Practice By Households In Shah Alam, Selangor, Malaysia", "International Journal of Environmental Sciences", Volume 1, No 2, 2020, pp.132144.

[11] Bandung City, Environment Management Board, Feb.24, 14, RK www.waste.ccacoalition.org/sites/default/files/files/events_documents/ Bandung\$250City\%250Indonesia 0.pdf

[12] Insite Metrodata, (2012), Insite Metrodata, Majalah Kuartal untuk Stakeholders Metrodata.

[13] http://www.trikomseloke.com/EN/news_details.php?idnews=69

[14] I.A.H. Wijayanti, N.K. Seminari, (2013). Pengaruh Gaya Hidup Terhadap Perilaku Pembelian Mobile phone Blackberry dengan Merek Sebagai Pemoderasi. E-Jurnal Manajemen Universitas Udayana. [Online]. 2(6). pp. 639-653. Available: http://ojs.unud.ac.id/index.php/ Manajemen/article/view/5219.
[15] S. M. Budijati, Subagyo, M.A. Wibisono and N.A. Masruroh, "A Study of Consumers' Post Consumption Behaviour for Mobile Phone in Indonesia," Industrial Engineering, Management Science and Applications, Vol. 349 of the series Lecture Notes in Electrical Engineering, 2015, pp 563-573.

[16] J.H. Laurence, V. Anggrek, "Integrasi Model Simulasi Jaringan Reverse Logistics Sampah Elektronik dengan Metode Drop Off dalam Analisis Biaya Fasilitas Daur Ulang Sampah Elektronik Hasil Pengumpulan pada Wilayah DKI Jakarta,” Integra, Vol.1 No.2, 2011, pp. 218-234.

[17] www.galamedianews.com/foto/13218/kampanye-bahaya-sampahelektronik.html

[18] M. P. de Brito, R. Dekker, S.D.P. Flapper, "Reverse Logistics - A Review Of Case Studies," Working Paper/ERIM Report Series Research In Management, Version January 2003, unpublished.I 